\section{Landslide Hazards in Minnesota}

Landslides in Minnesota have caused loss of life, damaged infrastructure, and negatively affected Minnesota's natural resources. Landslides increase the amount of sediment contributed to lakes and rivers, with negative consequences for water quality and aquatic habitats. Landslidesusceptible areas within Minnesota primarily occur on steep slopes adjacent to rivers, lakes, and transportation corridors. Local variation in landslide susceptibility is related to the underlying geology and glacial history. At some point during repeated glaciations in the last 2 million years, glaciers covered every part of Minnesota. They deposited unconsolidated sediment which can vary widely in its material properties and therefore its stability. Flowing water from melting glaciers cut into the glacial sedimentary deposits, forming river valleys bounded by steep and potentially unstable slopes. In southeastern Minnesota, which was not glaciated in the most recent glacial period that ended 13,000 years ago, rivers have eroded through older glacial sediment and bedrock, and the steep bedrock slopes are prone to landslides that incorporate bedrock debris.

The most common type of landslides in Minnesota are shallow slope failures that occur during heavy rain; these are often less than 1-meter ( $\sim 3$ feet) deep but can erode the entire length of a slope. Rockfalls are common around cliffs - cracks in solid bedrock allow large blocks of rock to fall, sometimes during freeze-thaw cycles. Deeper landslides, debris flows, and mudflows are possible, but much less common in Minnesota than in more mountainous areas. Less destructive landslides such as slow-moving earthflows and soil creep can also occur when soil moisture and shallow groundwater saturate sediments.

Heavy rains that saturate soils, increase groundwater levels, cause stream flooding, and generate surface runoff across the landscape can also cause landslides. Observed and predicted increases in rainfall duration and intensity linked to climate change are expected to increase flood intensity and soil saturation in Minnesota, potentially increasing the occurrence of landslides. Changes in land use that may create conditions for landslides include alterations to slopes such

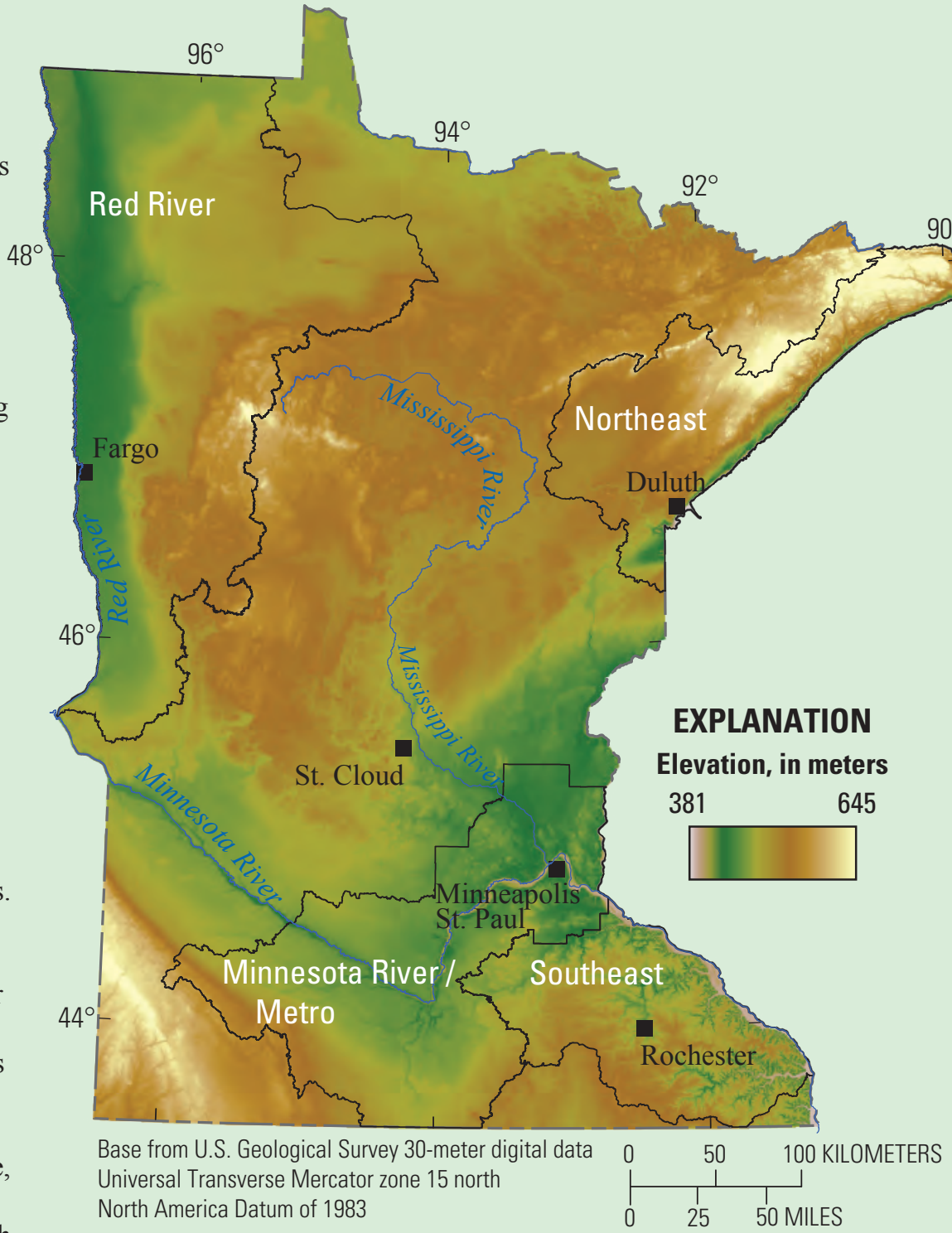

Regions of Minnesota where landslide activity has been mapped using lidar and other methods: Red River, Northeast, Minnesota River/Metro, and Southeast.

as undercutting, placement of artificial fill, and erosion of ravines from increased stormwater runoff as a result of development or agricultural practices.

Recent mapping of landslides focused on four areas of Minnesota-Red River, Northeast, Minnesota River/Metro, and Southeast — each with a unique geology, glacial history, and landslide susceptibility. This mapping relied on interpretation of light detection and ranging (lidar) topography, satellite and airborne imagery, and field investigation to reveal the location of almost 10,000 identifiable landslides. 


\section{Red River: Cutting the Glacial Lake Plain of Northwestern Minnesota}

The Red River valley in northwestern Minnesota was originally the bed of an extensive lake filled by glacial meltwater into which fine sand, silt, and clay were deposited. The Red River and its tributaries have since cut down into the flat lake plain, forming steep slopes adjacent to channels. These slopes, which can be completely covered in water during extensive floods, are prone to landslides.

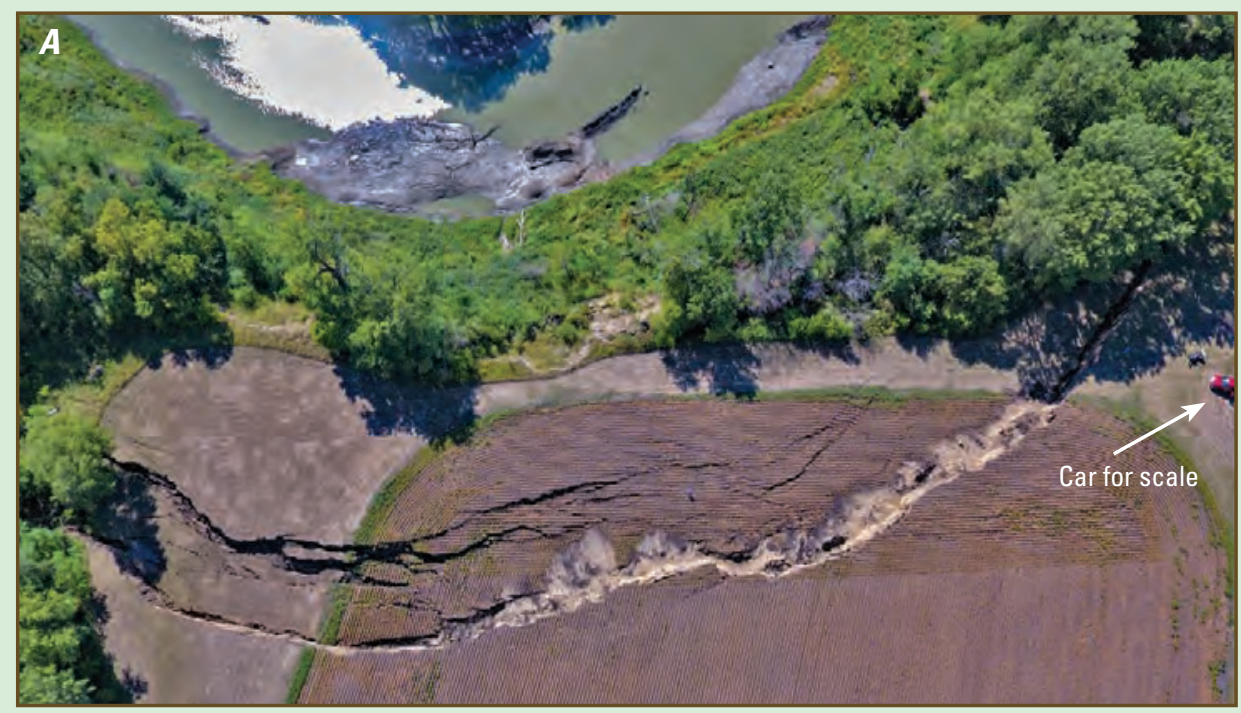

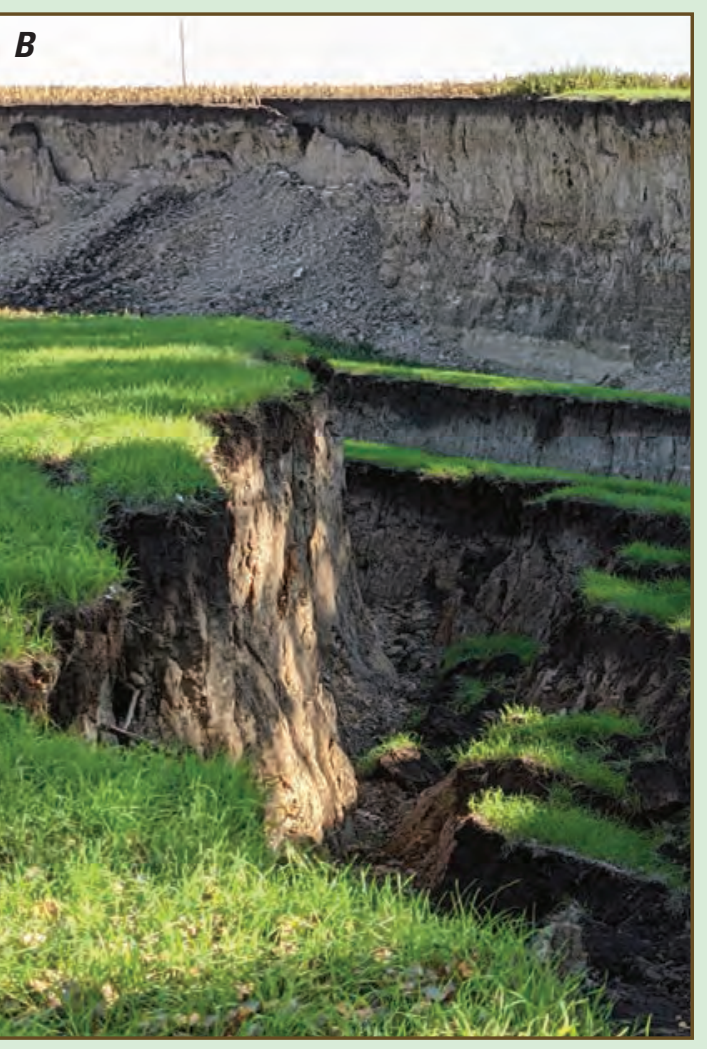

Landslide formed in glacial lake sediments adjacent to the Red River in 2021. A, An overhead view taken from a small unmanned aerial vehicle. Scarps formed in the field and clay-rich sediment that flowed from the base of the streambank are visible in the river channel at the top of image. Note the red vehicle at the right edge of the photograph for scale. $B$, view taken from the ground that shows down-dropped landslide blocks that fell 6 meters (20 feet) from the surface at the top of the photograph. Photographs courtesy of Brad Thoreson $(A)$ and North Dakota State University $(B)$.

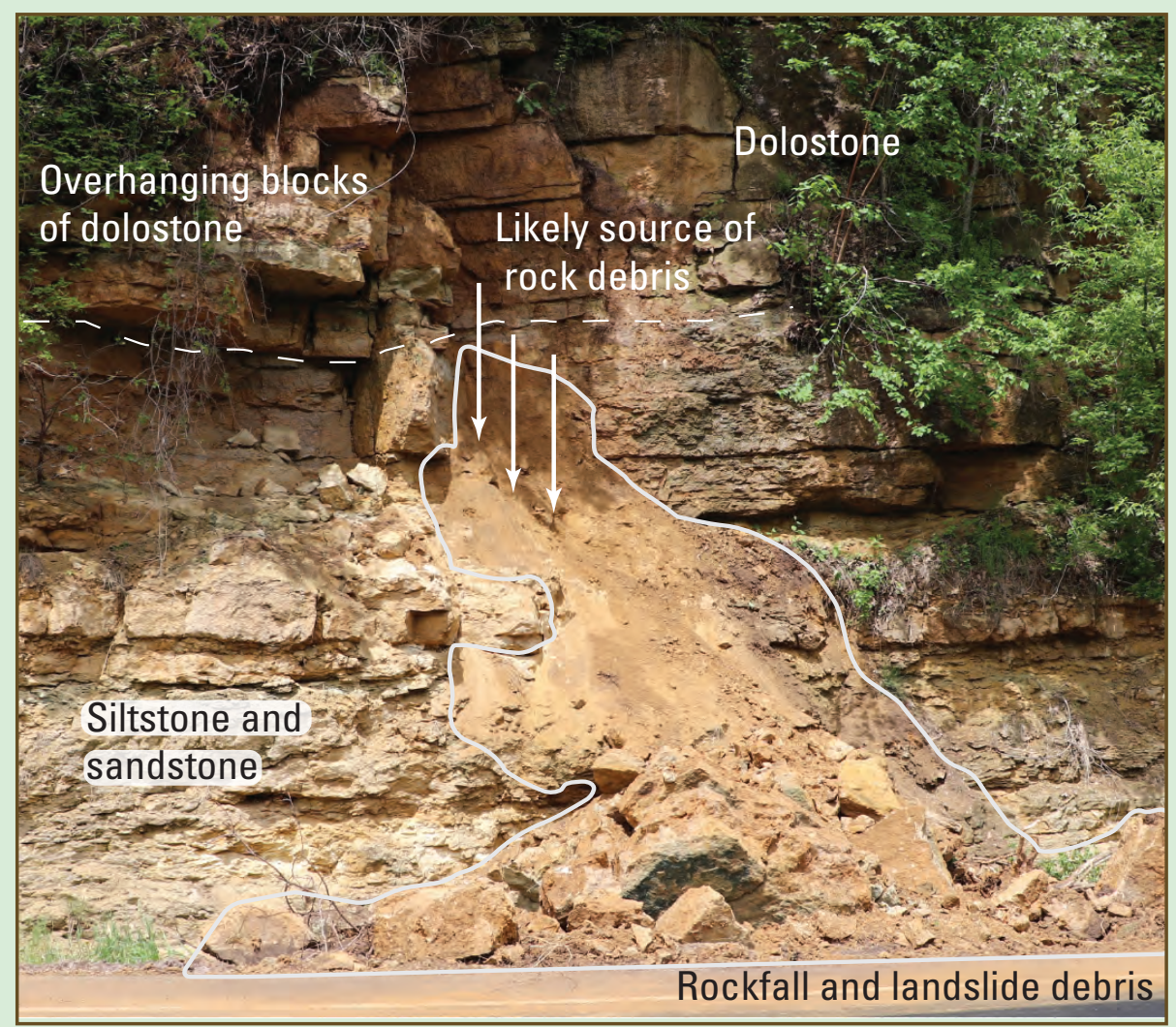

Layered bedrock in southeastern Minnesota and rockfall. In this location, weaker siltstone and sandstone layers are beneath stronger carbonate rock layers. As the siltstone and sandstone are eroded, blocks of the overlying dolostone (above dashed line) are undermined and can fail abruptly. Photograph courtesy of Winona State University.

\section{Southeast: Minnesota Bluff Country}

Tributaries to the Mississippi River in southeastern Minnesota have stream channel networks cut into flat-lying, layered sedimentary bedrock. Much of this region was not ice-covered during the most recent glacial period, so it lacks the youngest glacial sediments found elsewhere. Bedrock, which can be quite resistant to erosion, is covered by weathered rock and soil, and in some places, by older glacial and wind-blown sediments, all of which can be involved in landslides.

Weathering-resistant rocks such as limestone, dolostone, and well-cemented sandstone can form unstable overhangs and blocks that fall from bluffs when exposed above layers composed of weaker materials such as poorly cemented sandstone, siltstone, and shale. Carbonate rocks are prone to chemical dissolution, which forms caves and sinkholes that can convey water to springs at the base of steep slopes and cause landslides.

Landslides occur on the steep bluffs adjacent to the Mississippi River and its many tributary valleys; they also occur along roadcuts and rivers where lateral erosion by rivers has steepened adjacent slopes. Small rockfalls occur throughout the year, especially during freeze-thaw conditions, and during intense or prolonged rainfall. Landslides and rockfalls may occur where sedimentary layers of contrasting strengths are exposed on slopes. 


\section{Minnesota River: South-Central Minnesota and the Minnesota River Valley}

The Minnesota River in south-central Minnesota flows through a wide, deep valley that was largely formed by flowing glacial meltwater starting approximately 13,400 years ago. Today, tributaries to the Minnesota River continue to cut into the landscape, which has formed steep river bluffs in thick glacial sediments. These steep slopes may form in clay-rich or sandy deposits or fractured bedrock, all of which are prone to landslides during rainstorms. Some large landslides - visible in the landscape as arcuate scarps and lobes of sediment-may be prehistoric and appear inactive, but can be reactivated by intense or prolonged rainfall, river flooding, springs, or slope alteration. Runoff associated with land-use change and drainage practices across extensive upland agricultural landscapes may also increase landslide activity.
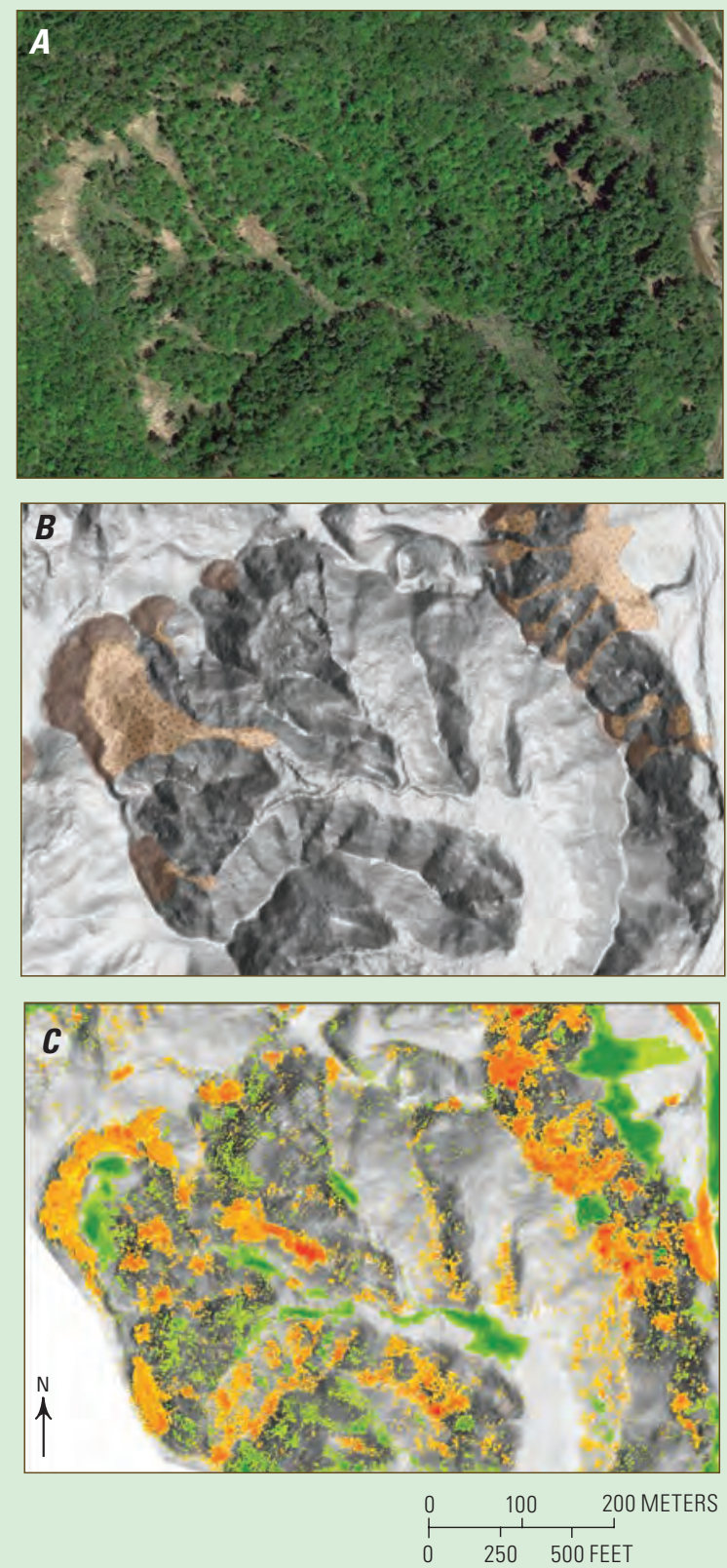

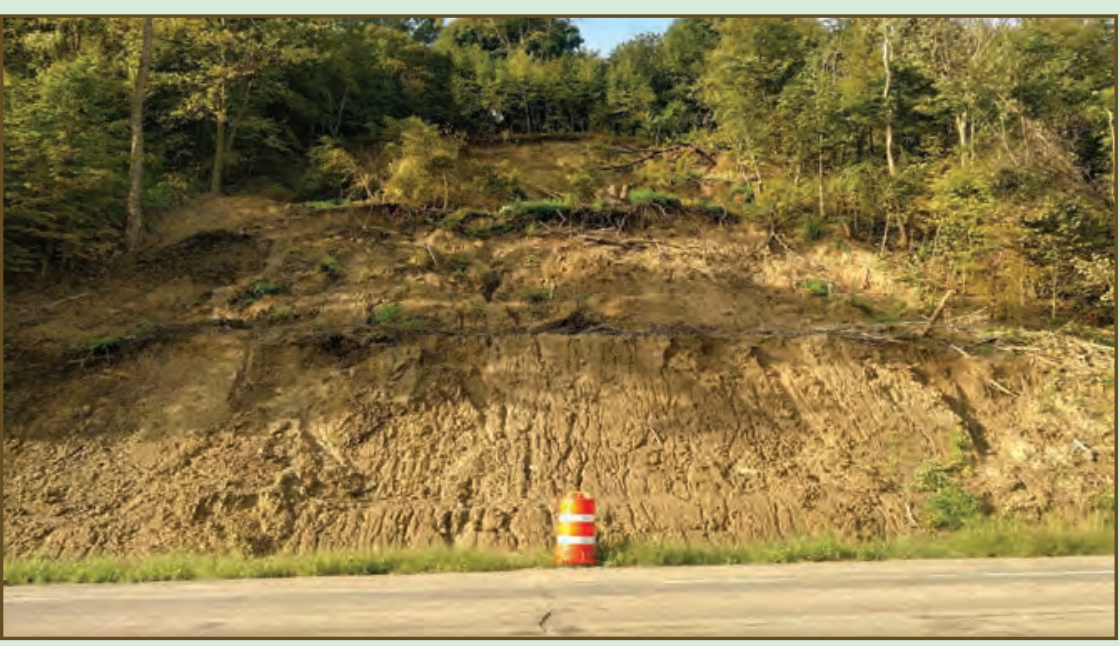

Located in glacial sediment along a roadcut in the Minnesota River valley, this landslide has been active multiple times. The horizontal bands of vegetation have moved downslope during rainstorms, and the slope has been destabilized as landslide debris is removed from the base of the slope to keep the roadway clear. Photograph courtesy of Minnesota State University, Mankato.

\section{Northeast: Bedrock and Glacial Sediment in the Lake Superior Watershed}

Landslides in northeastern Minnesota occur along the steep shorelines of Lake Superior and on slopes bordering stream valleys. The streams that flow into the north shore of Lake Superior cut into weak glacial sediments underlain by resistant bedrock. At the western end of Lake Superior, channels cut into unstable, fine-grained glacial lake sediment that was deposited during the last glacial period in a waterbody filled to a level higher than the current lake. These sediments are prone to landslides, which occur as a result of increased soil moisture and runoff during storms, steepening of slopes by river erosion at the base of slopes, and groundwater seepage. Rockfalls occur along cliffs made of fractured bedrock that are affected by freeze/thaw cycles, vegetation root growth, and other weathering processes.

In June 2012, a remarkable rainstorm centered on Duluth, Minnesota caused extensive landslides and flooding. Analysis of lidar data collected before and after the storm revealed that landslides were common along stream valleys and were particularly extensive in areas of clay-rich sediment deposited by glaciers and from glacial lake deposits. Thousands of individual landslides occurred, mobilizing millions of cubic meters of sediment from landslides and valley-floor erosion by river flooding; this amount of sediment can have significant negative impacts on aquatic habitats.

Light detection and ranging (lidar) data, collected by laser instruments onboard aircraft, show precise ground elevations and can be used to discover landslides. In $(A)$, landslide scarps are evident in a satellite image. In $(B)$, which shows the same area, mapped landslides (orange pattern) can be seen in a lidar-derived shaded relief map. In $(C)$, a map of elevation changes (orange and red are erosion, shades of green are deposition) made from comparison of two lidar surveys collected before and after a large storm that occurred in 2012. The area depicted is in part of the Mission Creek watershed near Duluth, in northeastern Minnesota. Upper panel image courtesy of Maxar. 


\section{Metro: Urban Landslide Hazards}

The valleys of the Minnesota and Mississippi Rivers in the greater Minneapolis and Saint Paul metropolitan area were eroded by flowing water from melting glaciers more than 10,000 years ago, and from ongoing erosion since the end of glacial melting. Steep river bluffs have formed in layered sedimentary bedrock of variable strength and are covered in places by loose sandy sediments from earlier glacial meltwater flow and by other sediments that are prone to landslides during significant rainstorms. Groundwater springs can weaken, erode, and saturate bedrock layers and cause landslides. These natural causes of landslides can be exacerbated by human activities, like oversteepening of slopes.

In urban areas, human activities affect slopes by (1) concentrating stormwater runoff from impermeable surfaces like buildings, parking lots, and roads; (2) steepening slopes adjacent to roads and rail corridors; (3) adding weight to slopes with structures and artificial fill; and (4) weakening slopes with infiltrated water or by removing material. These activities can increase landslide hazards on slopes that were already susceptible to landslides.

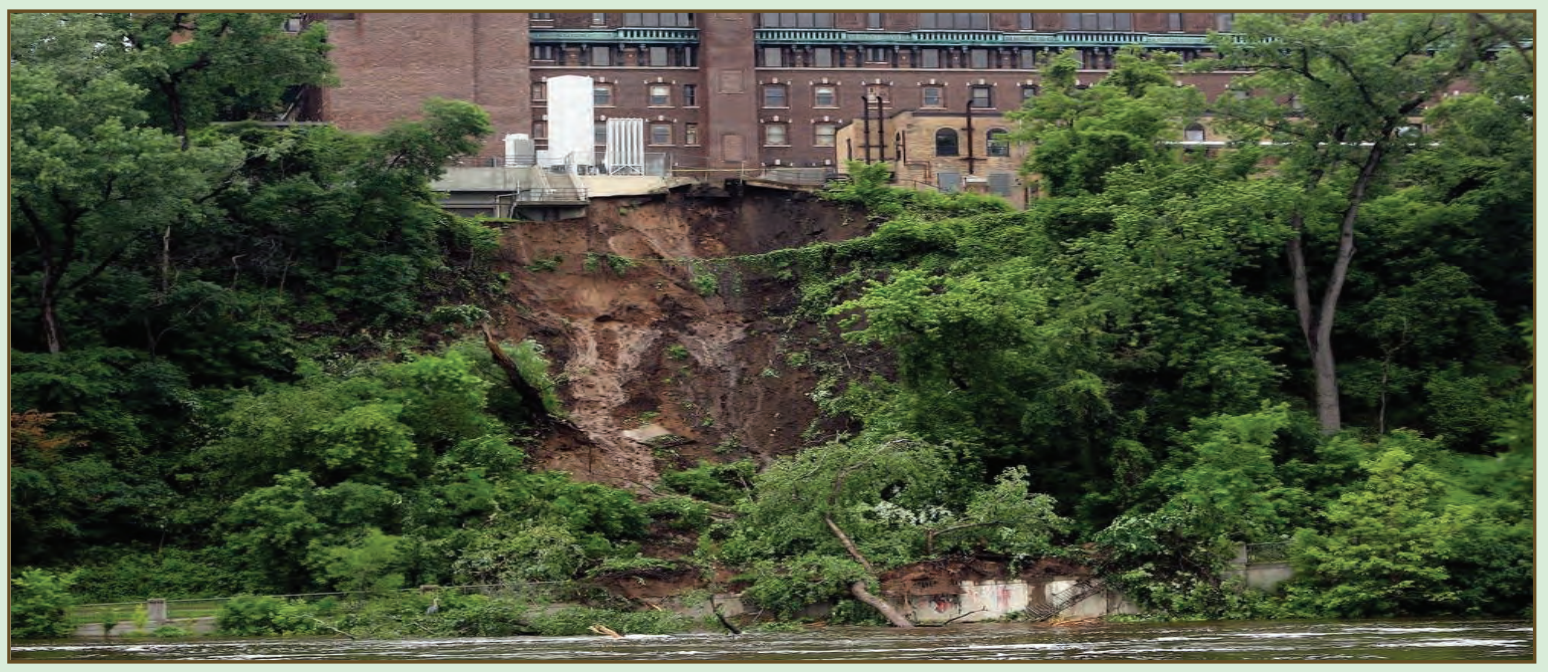

In 2014, heavy rainfall caused a landslide beneath a hospital at the University of Minnesota. The failure occurred in artificial fill, which can be much less stable than natural sediments. Photograph from Minnesota Public Radio News. Copyright 2016 Minnesota Public Radio, used with permission, all rights reserved.

\section{What are the Factors that Lead to Landslides in Minnesota?}

The steeper parts of the landscape in Minnesota are prone to landslides for a number of reasons:

- Steep slopes exist along stream valleys formed by glacial meltwater erosion and by the ongoing incision and lateral migration of tributary streams.

- Stream flooding erodes laterally into the base of steep slopes, creating unstable slopes.

- Clay-rich glacial sediment is prone to failure when saturated by rainfall and groundwater.

- Sandy, loose, glacial sediment deposited by glacial meltwater rivers is weak and prone to failure.

- Layered sedimentary bedrock generates rockfall as weaker layers are eroded beneath stronger layers.

- Human factors including inadequate storm water management, undercutting of slopes, placement of artificial fill, and land-use changes such as urbanization and agricultural practices can lead to erosion and landslides.

- Climate change is causing more extreme rainstorms that may occur more frequently than in the past.

\section{Where to Go for More Information}

1. The U.S. Geological Survey Landslide Program has information, publications, and educational information on its Web site at http://landslides.usgs.gov or call (toll-free) 1-800-654-4966.

2. A recent landslide inventory of the areas described here can be found in a U.S. Geological Survey data release at https://doi.org/10.5066/P94KF6OM.

3. For more information on the effects of the 2012 Duluth storm see the U.S. Geological Survey Scientific Investigations Reports at https://pubs.usgs.gov/sir/2012/5283/ and https://pubs.er.usgs.gov/publication/sir20165104.

4. For an assessment of the landslide risk to an individual property or homesite, obtain the services of a state-licensed geotechnical engineer or engineering geologist. These professionals can be found through the membership listings of two professional societies, the American Society of Civil Engineers (http://www.asce.org) and the Association of Engineering Geologists (http://www.aegweb.org). Often, personnel in state or county planning or engineering departments can suggest competent geotechnical engineers or engineering geologists.

By Stephen B. DeLong, U.S. Geological Survey

Carrie E. Jennings, Freshwater Society

Karen B. Gran, University of Minnesota Duluth Edited by Katherine Jacques

Layout and Design by Kimber Petersen 